\title{
Indexes of the Foreign Exchange Value of the Dollar
}

Mico Loretan, of the Board's Division of International Finance, prepared this article. Autria Mazda and Sarita Subramanian provided research assistance.

At the end of 1998, the staff of the Federal Reserve Board introduced a new set of indexes of the foreign exchange value of the U.S. dollar. ${ }^{1}$ The staff made the changeover, from indexes that had been used since the late 1970s, for two reasons. First, five of the ten currencies in the staff's previous main index of the dollar's foreign exchange value were about to be replaced by a single new currency, the euro. Second, developments in international trade since the late 1970s called for a broadening of the scope of the staff's dollar indexes and a closer alignment of the currency weights with U.S. trade patterns.

Exchange rate indexes aggregate and summarize information contained in a collection of bilateral foreign exchange rates. Choices concerning the exchange rates to include, the formula to use in combining the component exchange rates into a single number, and the weights to assign the exchange rates in an index all depend importantly on the objectives of the index. The main objective of the staff's current indexes is to summarize the effects of dollar appreciation and depreciation against foreign currencies on the competitiveness of U.S. products relative to goods produced by important trading partners of the United States. The staff also uses some of the indexes-those that track the dollar's moves

1. See Michael P. Leahy (1998), "New Summary Measures of the Foreign Exchange Value of the Dollar," Federal Reserve Bulletin, vol. 84 (October), pp. 811-18. That article, the time series of the dollar indexes, and the time series of the currency weights are available on line at the Board's public website (www.federalreserve.gov). Values of the dollar indexes for recent months and years also appear in table 3.28 of the monthly Statistical Supplement to the Federal Reserve Bulletin and are available through several financial news services. Earlier Bulletin articles on exchange rate indexes include B. Dianne Pauls (1987), "Measuring the Foreign Exchange Value of the Dollar," vol. 73 (June), pp. 411-22; Peter Hooper and John Morton (1978), "Summary Measures of the Dollar's Foreign Exchange Value," vol. 64 (October), pp. 783-89; and "Index of the Weighted-Average Exchange Value of the U.S. Dollar: Revision" (1978), vol. 64 (August), p. 700. against only the major foreign currencies-to gauge financial market pressures on the dollar.

To capture the evolving nature of international trade patterns, the staff's current exchange rate indexes allow changes in the component exchange rates and their weights. The currency weights in the dollar indexes are based on annual trade data, vary by year, and have been updated annually since 1998 . Although the set of exchange rates in the indexes has remained unchanged so far, the staff will continue to review whether changes in composition or methodology are needed to ensure that the indexes adequately reflect ongoing developments in international trade patterns.

Several practical aspects of the design and implementation of the current indexes - the choice of index formula, the design of currency weights, and the selection of currencies-are discussed in this article. The article also reviews the performance of the indexes over the past twenty-five years and discusses the three minor methodological changes that the indexes have undergone since their introduction.

\section{CHOICE OF INDEX FORMULA}

The practice followed by the staff of the Board and by that of several other central banks, international organizations, and private-sector financial institutions is to use exchange rate indexes that are geometrically weighted averages of bilateral exchange rates. ${ }^{2}$ The Board staff's nominal dollar exchange rate index at time $t, I_{t}$, is

$$
I_{t}=I_{t-1} \times \prod_{j=1}^{N(t)}\left(e_{j, t} / e_{j, t-1}\right)^{w_{j, t}},
$$

2. For more information on various index forms and their mathematical properties, see W. Erwin Diewert (1987), "Index Numbers," in John Eatwell, Murray Milgate, and Peter K. Newman, eds., The New Palgrave: A Dictionary of Economics, vol. 2 (New York: Stockton), pp. 767-80. For descriptions of the sterling and euro exchange rate indexes currently used, for example, by the staff of the Bank of England and the European Central Bank, see Birone Lynch and Simon Whitaker (2004), “The New Sterling ERI," Bank of England Quarterly Review (Winter), pp. 429-41; and "Effective Exchange Rate of the Euro" (2004), European Central Bank Monthly Bulletin (September), pp. $68-72$. 
where $I_{t-1}$ is the value of the index at time $t-1$, $e_{j, t}$ and $e_{j, t-1}$ are the prices of the U.S. dollar in terms of foreign currency $j$ at times $t$ and $t-1$, $w_{j, t}$ is the weight of currency $j$ in the index at time $t$, $N(t)$ is the number of foreign currencies in the index at time $t$, and $\sum_{j} w_{j, t}=1 .^{3}$ Because the weights are based on annual data on international trade, they are constant within a calendar year, as is explained later in more detail.

The staff chose geometric rather than simple arithmetic averaging for its exchange rate indexes because under geometric averaging, proportionately equal appreciation and depreciation of a currency has the same numerical effect (though of opposite sign) on the index. In an arithmetically averaged exchange rate index, such changes result in an upward bias in the index for the dollar. The upward bias is less of a problem if major components move in the same direction, but this condition is often not met by bilateral exchange rates. ${ }^{4}$

If a currency depreciates persistently-for example, because of high domestic inflation-an exchange rate index that includes that currency will increase markedly even if the currency's weight is small. ${ }^{5}$ When inflation experiences abroad differ significantly from those in the United States, real rather than nominal exchange rates are more informative for measuring changes in trade competitiveness. The staff's real exchange rate indexes are obtained by replacing the nominal exchange rates, $e_{j, t}$, with their real counterparts, $e_{j, t} \cdot p_{t} / p_{j, t}$, where $p_{t}$ and $p_{j, t}$ are consumer price indexes for the United States and economy $j{ }^{6}$

3. The formula allows both the number of exchange rates in the index and the weights of the exchange rates to vary over time. Calculating the index is simplified considerably, of course, if the number of currencies and the currency weights remain unchanged. In such a case, the index calculations are said to "telescope"- that is, the net change in the index over a period depends only on the net changes in the bilateral exchange rates but not on the trajectories of the rates.

4. The staff has used geometrically averaged exchange rate indexes since 1978. The Laspeyres and Paasche indexes are examples of arithmetically averaged indexes.

5. For an illustration of the effects of currency depreciation on a nominal index, see the later discussion of the evolution of the staff's broad nominal dollar index over the past twenty-five years.

6. The set of internationally traded goods may not be well approximated by the baskets of goods purchased by consumers in various countries. In general, producer price indexes tend to be better measures of inflation for gauging changes in real international competitiveness. Unfortunately, producer price indexes are not as widely available as consumer price indexes. Consumer price indexes have the important additional advantage of being available at monthly frequencies and with little delay for most economies of interest, including all economies whose currencies are in the exchange rate indexes.

\section{DESIGN OF CURRENCY WEIGHTS}

To create an operational exchange rate index, one must not only choose a formula for aggregating bilateral exchange rates into a single number but also devise methods for calculating the weights of those currencies and for selecting the currencies to be included in the index. Because the staff's exchange rate indexes are intended primarily to measure the competitiveness of U.S. goods in international trade, the exchange rates in the indexes are those of economies that figure importantly in international trade with the United States. These economies can be important either because the United States imports substantial amounts of goods from them or because the United States exports products that compete with goods produced in those economies. Exchange rates influence competitiveness because they affect the relative prices of goods as perceived by sellers and buyers. The weights associated with each of the currencies are designed to reflect the importance of the respective economies for trade competition. ${ }^{7}$

Competition in traded goods occurs in both domestic and foreign markets. In U.S. markets, goods that are produced abroad and are imported to the United States compete with domestically produced goods. To capture this form of trade competition, economy $j$ 's share of total U.S. merchandise imports is chosen as that economy's bilateral import weight during period $t$ :

$$
\mu_{U S, j, t}=M_{U S, j, t} / \sum_{j=1}^{N(t)} M_{U S, j, t},
$$

where $M_{U S, j, t}$ represents the merchandise imports from economy $j$ to the United States in year $t .^{8}$ Because trade patterns generally move little over short periods of time, the staff chose to base the import weights (and the other measures of trade competition introduced in the next two paragraphs) on annual rather

7. The staff's system of currency weights is based on a stylized model of international trade in differentiated products. For an overview of that model, see Leahy, "New Summary Measures"; for a full exposition, see Anne K. McGuirk (1986), "Measuring Price Competitiveness for Industrial Country Trade in Manufactures," IMF Working Paper WP/87/34 (Washington: International Monetary Fund). This trade model suggests that only trade in differentiated products is affected by exchange rate fluctuations, and it also implies that all international trade in undifferentiated products (and hence in most primary commodities) should be excluded to obtain the appropriate currency weights.

8. Unfortunately, data limitations make the consistent exclusion of most commodities from bilateral merchandise trade statistics impractical. However, the calculations exclude imports of crude oil to the United States. 
than higher-frequency trade data to simplify the index calculations. Therefore, the weights are constant within a calendar year.

Tradable goods produced in the United States compete with those from economy $j$ in two additional ways. First, economy $j$ may be a direct purchaser of U.S. products. This form of trade competition is measured by that economy's U.S. bilateral export share:

$$
\varepsilon_{U S, j, t}=X_{U S, j, t} / \sum_{j=1}^{N(t)} X_{U S, j, t}
$$

where $X_{U S, j, t}$ represents the merchandise exports from the United States to economy $j$ in year $t .{ }^{9}$

Second, U.S.-produced goods may also compete with goods produced in economy $j$ if the United States and economy $j$ both export goods to buyers in third-market economies. To measure this form of competition, the staff calculates third-market competitiveness weights. These weights are defined as

$$
\tau_{U S, j, t}=\sum_{k \neq j, k \neq U S}^{N(t)} \varepsilon_{U S, k, t} \cdot \mu_{k, j, t} /\left(1-\mu_{k, U S, t}\right),
$$

where $\mu_{k, j, t}$ is the fraction of economy $k$ 's merchandise imports from country $j$ in year $t$ and where $k \neq j$. The multiplicative factor $1 /\left(1-\mu_{k, U S, t}\right)$ ensures that the weights sum to $1 .{ }^{10}$ The U.S. third-market competitiveness weight of economy $j$ is a weighted average of the third-market economies' U.S. bilateral export shares, where the weights are given by $j$ 's bilateral shares of those economies' imports. ${ }^{11}$ Hence, the U.S. third-market competitiveness weight of economy $j$ is large if economy $j$ figures prominently in the imports of those economies for which the United States has large bilateral export weights.

The overall, or combined, weights of the currencies in the dollar indexes are calculated as the follow-

9. The computations of the bilateral export weights exclude U.S. exports of gold and military goods. For the first few years after the current indexes were introduced, the computations also excluded U.S. agricultural exports, but the staff decided in 2002 to drop that exclusion. This methodological change is discussed in more detail later in this article.

10. In principle, the bilateral import weights $\mu_{k, j, t}$ for $k \neq U S$ should exclude oil imports (and, ideally, other primary commodities) to ensure symmetric treatment with the U.S. bilateral import weights. However, data limitations make this adjustment infeasible for several countries that are major U.S. trading partners. Therefore, the bilateral import weights used by the staff in its calculations of U.S. third-market competitiveness weights include oil imports.

11. The U.S. third-market competitiveness weight of economy $j$ can also be interpreted as a weighted average of $j$ 's bilateral shares of the third-market economies' imports, where the weights are given by those economies' U.S. bilateral export shares. ing linear combination of the three submeasures of the degree of trade competition:

$$
w_{j, t}=\frac{1}{2} \mu_{U S, j, t}+\frac{1}{2}\left(\frac{1}{2} \varepsilon_{U S, j, t}+\frac{1}{2} \tau_{U S, j, t}\right) .
$$

The coefficients of the three submeasures were chosen to give equal importance to competition from imports in U.S. markets and to competition from U.S. exports in foreign markets. ${ }^{12}$ In addition, equal importance is given to the bilateral export weights and to the weights that summarize competition in third markets. ${ }^{13}$

\section{SELECTION OF CURRENCIES}

The staff selected currencies for inclusion in three indexes: the broad index, the major currencies index, and the other important trading partners (OITP) index. The following sections describe these indexes and the associated processes of currency selection.

\section{The Broad Index}

The currencies chosen for inclusion in the broad dollar index in 1998 were determined pragmatically as those of economies whose bilateral shares of U.S. imports or exports exceeded $1 / 2$ percent in 1997, the latest year for which complete annual trade data were then available. On the basis of this criterion, the staff selected twenty-six currencies. Anticipating the adoption of the euro at the end of 1998 by eleven member countries of the European Union (EU), the staff designed the index so that a single weight for the euro could capture the influence of the dollar-euro exchange rate on trade competition between the United States and the euro area. ${ }^{14}$

12. This choice is somewhat arbitrary. Changing the relative importance of the three submeasures of the degree of trade competition obviously affects the overall currency weights and hence may affect the exchange rate indexes. Although varying the relative importance of the three submeasures would have affected the trajectories of the dollar indexes somewhat during the 1970s and the early 1980s, such variations mattered fairly little from about 1985 on, at least when some appreciable weight is given to each of the three submeasures. The staff therefore chose to maintain its current set of weights on the three submeasures.

13. Empirical work done in 1998 with the staff's trade model showed that an equal weighting of the two measures of export competitiveness performed well in explaining U.S. core exports, and this performance provided a rationale for giving equal importance to these two measures. Core exports are merchandise exports other than agricultural goods, computers, and semiconductors.

14. The shares of the eleven initial euro-area countries in U.S. imports and exports were summed to obtain the bilateral import and export weights of the aggregate euro-area economy for the years 
1. Share of U.S. imports, by economy, 1997 and 2003 Percent except as noted

\begin{tabular}{|c|c|c|c|}
\hline Economy & 1997 & 2003 & $\begin{array}{l}\text { Change } \\
\text { (percentage } \\
\text { points) }\end{array}$ \\
\hline Canada . & 19.55 & 17.78 & -1.77 \\
\hline Euro area & 14.18 & 16.22 & 2.04 \\
\hline China .... & 7.77 & 13.53 & 5.76 \\
\hline Mexico & 9.70 & 10.90 & 1.20 \\
\hline Japan $\ldots \ldots \ldots \ldots$ & 15.21 & 10.49 & -4.72 \\
\hline United Kingdom & 3.82 & 3.31 & -.51 \\
\hline Korea ............ & 2.88 & 3.27 & .39 \\
\hline Taiwan ... & 4.08 & 2.80 & -1.28 \\
\hline Malaysia & 2.23 & 2.24 & .01 \\
\hline Brazil ... & 1.18 & 1.41 & .23 \\
\hline Thailand .. & 1.58 & 1.35 & -.23 \\
\hline Singapore . & 2.50 & 1.34 & -1.16 \\
\hline India $\ldots . .$. & .91 & 1.14 & .23 \\
\hline Israel $\ldots . .$. & .92 & 1.13 & .21 \\
\hline Switzerland & 1.06 & .97 & -.09 \\
\hline Sweden .... & .90 & .96 & .06 \\
\hline Philippines & 1.31 & .89 & -.42 \\
\hline Indonesia .. & 1.09 & .81 & -.28 \\
\hline Hong Kong & 1.29 & .79 & -.50 \\
\hline Australia ... & .53 & .54 & .01 \\
\hline Russia ... & .53 & .47 & -.06 \\
\hline Colombia & .33 & .32 & -.01 \\
\hline Chile .... & .29 & .32 & .03 \\
\hline Venezuela & .21 & .17 & -.04 \\
\hline Argentina ... & .21 & .16 & -.05 \\
\hline Saudi Arabia & .07 & .07 & .00 \\
\hline Total & 94.33 & 93.38 & -.95 \\
\hline
\end{tabular}

Note. Imports exclude oil. Here and in the following tables, components may not sum to totals because of rounding.

SouRCE. International Monetary Fund (various years), Direction of Trade Statistics (Washington: IMF); Census and Statistics Department (various years), Annual Review of Hong Kong External Trade (Hong Kong: CSD); Directorate General of Budget, Accounting, and Statistics (various years), Statistical Yearbook of the Republic of China (Taipei: DGBAS); Directorate General of Customs (various years), Monthly Statistics of Exports: Taiwan District, the Republic of China, December Issue, Part 2 (Taipei: DGC); Directorate General of Customs (various years), Monthly Statistics of Imports: Taiwan District, the Republic of China, December Issue (Taipei: DGC).

Trade with the twenty-six economies represented in the broad index accounted for well over 90 percent of total U.S. imports and exports in 1997 (tables 1 and 2). Although the U.S. import and export weights of several of these economies have shifted in the intervening years, in some cases considerably, these twenty-six economies still accounted for more than 90 percent of U.S. trade in 2003. Changes in U.S. trading patterns are also reflected in changes in some of the U.S. bilateral import and export shares. For example, between 1997 and 2003, the largest

before and after the creation of the euro. Because trade among the euro-area countries does not affect the competitiveness of euro-area and U.S. products in third markets, the staff chose in 1998 to exclude trade among the economies of the EU when calculating the U.S. third-market competitiveness weights, again for the years before and after the creation of the euro. This methodology was modified in 2003, as is described later. For the years before the creation of the euro, the broad index is based on dollar exchange rates for thirty-five currencies, and index calculations for those years use separate currency weights for the ten precursor currencies that merged into the euro at the end of 1998. The currency weights for the ten precursor currencies can be summed to obtain an implied weight for the eleven-country euro area. (Belgium and Luxembourg used the same currency before both countries adopted the euro.)
2. Share of U.S. exports, by economy, 1997 and 2003 Percent except as noted

\begin{tabular}{|c|c|c|c|}
\hline Economy & 1997 & 2003 & $\begin{array}{c}\text { Change } \\
\text { (percentage } \\
\text { points) }\end{array}$ \\
\hline Canada ... & 23.28 & 23.90 & .62 \\
\hline Euro area & 14.57 & 15.52 & .95 \\
\hline Mexico .. & 10.69 & 13.71 & 3.02 \\
\hline Japan .. & 8.78 & 7.12 & -1.66 \\
\hline United Kingdom & 5.42 & 4.48 & -.94 \\
\hline China ............ & 1.81 & 4.00 & 2.19 \\
\hline Korea ........... & 3.52 & 3.28 & -.24 \\
\hline Taiwan $\ldots \ldots$. & 2.68 & 2.40 & -.28 \\
\hline Singapore .. & 2.80 & 2.28 & -.52 \\
\hline Hong Kong & 2.14 & 1.91 & -.23 \\
\hline Australia ... & 1.88 & 1.79 & -.09 \\
\hline Brazil .... & 2.48 & 1.57 & -.91 \\
\hline Malaysia & 1.60 & 1.53 & -.07 \\
\hline Philippines & 1.06 & 1.12 & .06 \\
\hline Israel $\ldots . .$. & .75 & .86 & .11 \\
\hline Switzerland & .78 & .84 & .06 \\
\hline Thailand ....... & 1.05 & .79 & -.26 \\
\hline India $\ldots . . .$. & .56 & .69 & .13 \\
\hline Saudi Arabia & 1.04 & .60 & -.44 \\
\hline Colombia ... & .75 & .52 & -.23 \\
\hline Sweden ... & .50 & .44 & -.06 \\
\hline Venezuela & .97 & .39 & -.58 \\
\hline Chile .... & .69 & .38 & -.31 \\
\hline Indonesia & .61 & .35 & -.26 \\
\hline Russia ... & .35 & .34 & -.01 \\
\hline Argentina & .88 & .34 & -.54 \\
\hline Total & 91.64 & 91.18 & -.46 \\
\hline
\end{tabular}

NoTE. Exports exclude gold and military items.

Source. See table 1.

increases in U.S. bilateral import shares were recorded by China (53/4 percentage points) and the euro area ( 2 percentage points) (table 1$)$. In contrast, Japan's share of U.S. imports dropped 43/4 percentage points, and the U.S. import shares of Canada, Taiwan, and Singapore decreased $1-13 / 4$ percentage points. Meanwhile, the largest increases in U.S. bilateral export shares were recorded by Mexico (3 percentage points) and China (nearly 21/4 percentage points), and the largest decreases were registered by Japan, the United Kingdom, and Brazil, whose export shares declined $1-13 / 4$ percentage points (table 2 ).

In 2003, no economies excluded from the broad dollar index had shares of total U.S. imports or exports that exceeded $1 / 2$ percent. ${ }^{15}$ For example, none of the U.S. bilateral import and export shares of the ten countries (located mainly in central and eastern Europe) that were admitted to membership in the EU in 2004 reached 1/4 percent. Hence, the staff chose not to augment its indexes with additional currencies at this time. ${ }^{16}$

15. A second, necessary condition for including a currency in the staff's dollar indexes is ready availability of consumer price data for the economy in question.

16. When an additional EU member country adopts the euro as its currency, the staff will factor its trade into the calculation of the euro's weights in the dollar indexes. This treatment is analogous to the way the staff factored in Greece's trade flows when Greece adopted the euro as its currency in 2001. For more details on this action, see the discussion later in this article. 
3. Currency weights in the broad dollar index, 1997 and 2003

Percent except as noted

\begin{tabular}{|c|c|c|c|}
\hline Economy & $1997^{1}$ & 2003 & $\begin{array}{c}\text { Change } \\
\text { (percentage } \\
\text { points) }\end{array}$ \\
\hline Euro area $^{2}$ & 17.49 & 18.80 & 1.31 \\
\hline Canada $^{2}$.. & 16.92 & 16.43 & -.49 \\
\hline China ... & 6.58 & 11.35 & 4.77 \\
\hline Japan $^{2}$. & 14.27 & 10.58 & -3.69 \\
\hline Mexico $\ldots \ldots \ldots$ & 8.50 & 10.04 & 1.55 \\
\hline United Kingdom $^{2}$ & 5.73 & 5.17 & -.56 \\
\hline Korea...$\ldots \ldots \ldots$ & 3.68 & 3.86 & .18 \\
\hline Taiwan .... & 3.77 & 2.87 & -.90 \\
\hline Hong Kong ...... & 2.65 & 2.33 & -.32 \\
\hline Malaysia...$\ldots \ldots$ & 2.25 & 2.24 & -.01 \\
\hline Singapore ......... & 2.87 & 2.12 & -.75 \\
\hline Brazil ........ & 1.82 & 1.79 & -.03 \\
\hline Switzerland ${ }^{2}$ & 1.43 & 1.44 & .01 \\
\hline Thailand . & 1.59 & 1.43 & -.16 \\
\hline Australia $^{2}$. & 1.31 & 1.25 & -.06 \\
\hline Sweden $^{2} \ldots$ & 1.22 & 1.16 & -.06 \\
\hline India $\ldots \ldots$. & .88 & 1.14 & .26 \\
\hline Philippines . & 1.18 & 1.06 & -.12 \\
\hline Israel $\ldots \ldots \ldots$ & .84 & 1.00 & .16 \\
\hline Indonesia $\ldots \ldots \ldots \ldots \ldots$ & 1.25 & .95 & -.30 \\
\hline Russia $\ldots \ldots \ldots \ldots \ldots \ldots$ & .78 & .74 & -.04 \\
\hline Saudi Arabia & .80 & .61 & -.19 \\
\hline Chile...$\ldots \ldots$ & .53 & .49 & -.05 \\
\hline Argentina .... & .61 & .44 & -.18 \\
\hline Colombia $\ldots \ldots \ldots \ldots \ldots$ & .49 & .41 & -.08 \\
\hline Venezuela...$\ldots \ldots \ldots \ldots$ & .58 & .30 & -.27 \\
\hline Total & 100 & 100 & $\mathbf{0}$ \\
\hline $\begin{array}{c}\text { Memo: Major currencies } \\
\text { subtotal } \ldots \ldots \ldots \ldots \ldots\end{array}$ & 58.37 & 54.84 & -3.54 \\
\hline
\end{tabular}

1. Weights are different from those given in table 1 of Michael P. Leahy (1998), "New Summary Measures of the Foreign Exchange Value of the Dollar," Federal Reserve Bulletin, vol. 84 (October), pp. 811-18. The differences are due both to updated data for 1997 and to a change in methodology, which is discussed in this article.

2. Currency is in the major currencies index.

Source. See table 1.

Some of the combined currency weights-the linear combinations of bilateral import weights, bilateral export weights, and third-market competitiveness weights - of the twenty-six currencies in the broad dollar index underwent substantial changes between 1997 and 2003 (table 3). Reflecting the changes in U.S. bilateral import and export shares discussed earlier, the largest increases in currency weights were recorded by China (43/4 percentage points), Mexico ( $1 \frac{1}{2}$ percentage points), and the euro area (slightly more than $1 \frac{1 / 4}{4}$ percentage points), whereas the currency weight of Japan fell almost $33 / 4$ percentage points and the currency weights of Taiwan and Singapore declined $3 / 4-1$ percentage point. The euro and the Canadian dollar remain the currencies with the largest weights in the broad dollar index, whereas the currencies of China, Japan, and Mexico now have roughly equal weights at a slightly lower but still substantial level. In 2003, the sum of the currency weights of these five economies exceeded 67 percent.

The broad-index weights of these top five currencies evolved in different ways between 1980 and
1. Selected currency weights in the broad dollar index, 1980-2004

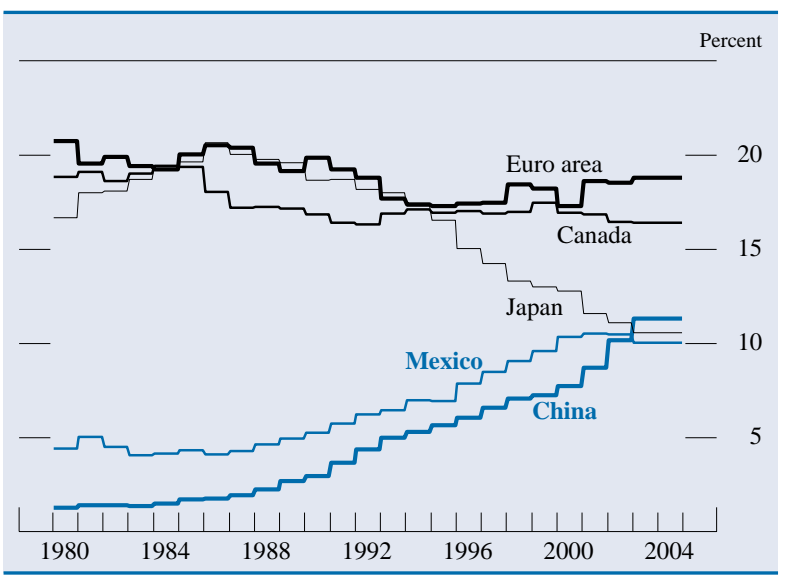

NoTE. Weights vary by year.

2004 (figure 1). ${ }^{17}$ The weight of the Japanese yen rose in the early 1980s but declined significantly throughout much of the 1990s, whereas the weights of the euro and the Canadian dollar, while fluctuating somewhat from year to year, changed little on balance. The weights of the Mexican peso and especially the Chinese renminbi increased steadily over time. Indeed, according to the latest available annual trade data, the weight of the renminbi in the broad index now exceeds that of the yen and the peso. Taken together, these fluctuations illustrate the importance of regularly updating currency weights if an exchange rate index is to capture the implications of changing patterns of trade for the competitiveness of U.S. products in international trade.

\section{The Major Currencies Index and the OITP Index}

Seven of the twenty-six currencies in the broad index - the euro, Canadian dollar, Japanese yen, British pound, Swiss franc, Australian dollar, and Swedish krona-trade widely in currency markets outside their respective home areas, and these currencies (along with the U.S. dollar) are referred to by the Board's staff as "major" currencies. The remaining nineteen currencies in the broad index are those of what the staff refers to as the "other important trading partners" (OITP) of the United States. On the basis of these distinctions, the staff created two subindexes of the broad dollar index that correspond to

17. For now, the weights in 2003 and 2004 are the same because they are both based on annual trade data for 2003. The weights for 2004 will be revised after trade data for that year become available. 
these two groups of currencies. The two subindexes, termed the major currencies index and the OITP index, track the trade-weighted exchange value of the dollar against the corresponding subsets of currencies. The weights of the currencies in the two subindexes are derived by rescaling the currencies' respective weights in the broad index so that they sum to 1 in each subindex. The share of the seven major currencies in the broad dollar index declined moderately between 1997 and 2003, from 58.4 percent to 54.8 percent, largely because of the growing relative importance of China and Mexico in U.S. international trade and the diminishing relative importance of Japan.

Because the major currencies generally trade in liquid financial markets, the major currencies index can be used to gauge financial market pressures on the dollar. In this role, the major currencies index is the successor to the staff's previous main dollar index, the so-called G-10 index, which the staff no longer maintains. A comparison of the performance of these two indexes and an examination of the causes of their different volatilities over certain time periods are provided in the following section.

Because most currencies are traded essentially continuously, the values of the nominal broad, major currencies, and OITP indexes can be computed on a daily basis or, if desired, at even higher frequencies. The highest frequency feasible for the corresponding real indexes, however, is monthly because these indexes require consumer price index data that are available only on a monthly basis.

\section{PERFORMANCE OF THE EXCHANGE RATE INDEXES, 1980-2004}

The staff's dollar indexes have been successful in summarizing major long-term fluctuations in the dollar's exchange value, as the major fluctuations in the real broad, major currencies, and OITP indexes over the past quarter-century correspond to identifiable events (some lasting several years) in foreign exchange markets (figure 2). The period of dollar appreciation in the early and mid-1980s and the subsequent prolonged period of dollar depreciation are tracked by the rise and subsequent fall of the real major currencies and real broad dollar indexes. The dollar's real appreciation against several Latin American currencies during the debt crisis of the early and mid-1980s is reflected in the sustained increase in the real OITP index over that period. The sharp real appreciation of the dollar (and of other major currencies) against the currencies of several
2. Real (price-adjusted) indexes of the foreign exchange value of the U.S. dollar, 1980-2004

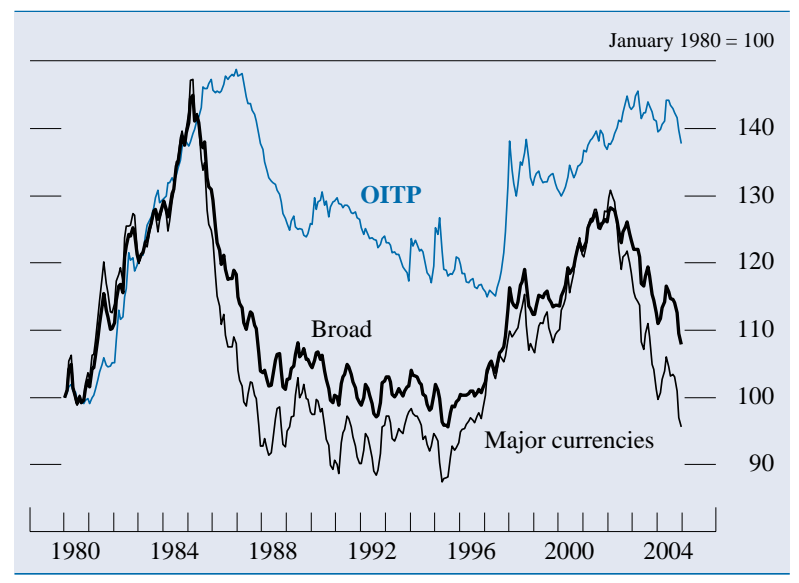

Note. Data are monthly.

Asian emerging-market economies in the wake of the Asian crisis of 1997-98 is reflected in the run-up of the real OITP index during that time. ${ }^{18}$ The period of broad-based dollar appreciation, which began in the late 1990s, and the recent period of sustained dollar depreciation, which began in early 2002 and has been especially pronounced against the major foreign currencies, are clearly visible in the fluctuations in the real major currencies index. The relative stability of the OITP index over the past three years contrasts markedly with the drop in the major currencies index and is due, at least in part, to the fact that the exchange values of several currencies with large weights in the OITP index are tied closely to the dollar.

In December 2004, the real broad and real major currencies indexes were about 8 percent above and 4 percent below their respective levels in January 1980 and were about 4 percent below and 11 percent below their respective twenty-five-year averages. The real broad and real major currencies indexes do not appear to show any identifiable long-term trends. ${ }^{19} \mathrm{In}$

18. Currencies of Asian and Latin American emerging-market economies make up the bulk of the OITP index.

19. The staff's exchange rate indexes have the property (shared by most chain-weighted indexes) that if the weights change over time but eventually return to their initial values and if all exchange rates also return to their initial values, the indexes will generally not return to their respective initial values. This potentially undesirable property can complicate the evaluation of longer-term changes in the indexes. To examine the empirical relevance of this potential difficulty for evaluating the apparent lack of a significant net change in the real broad and real major currencies indexes over the past twenty-five years, the staff considered alternative index formulas, such as those of fixed-weight indexes, which do not share this potential difficulty (but which, in turn, may have other potentially undesirable properties, such as an inability to reflect the changing patterns of trade flows). The staff found that the apparent lack of drift in the real broad and real major 
3. Nominal broad and OITP indexes of the foreign exchange value of the U.S. dollar, 1980-2004

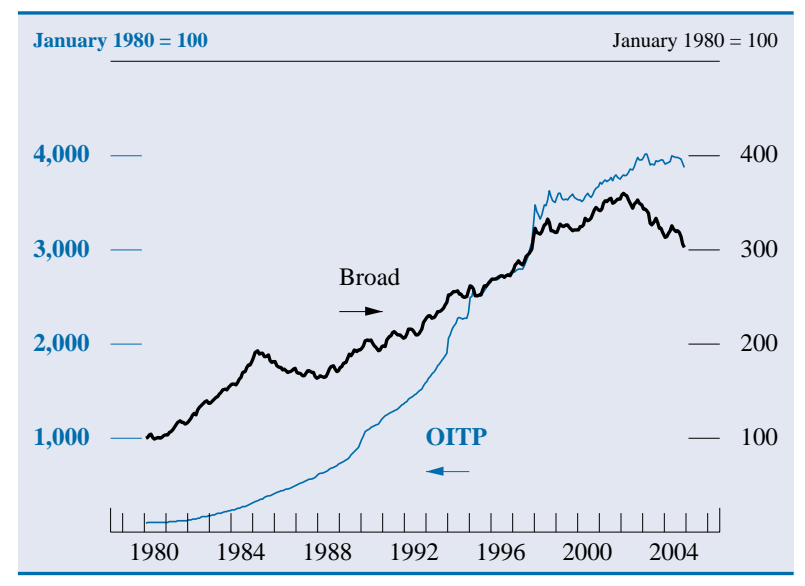

Note. Data are monthly averages of daily values.

contrast, at the end of 2004, the real OITP index was nearly 40 percent above its level in January 1980. The net increase appears mainly to reflect the sustained gain experienced during the 1980s, which was not fully reversed even as the real major currencies index declined substantially during the second half of the 1980s and in the early 1990s. Over the past twenty years, the real OITP index has changed little on balance. ${ }^{20}$

In contrast to the evolution of the real dollar indexes, the nominal broad index and especially the nominal OITP index have trended strongly upward since 1980 (figure 3). (Note that the vertical scales in figure 3 differ by a factor of ten.) The main reason for the sustained increase is that several of the currencies in the OITP index (and hence also in the broad index) have depreciated sharply in nominal terms, usually because of high inflation in the respective economies. The nearly fortyfold net increase in the nominal OITP index over this period stands in stark contrast to the net increase of about 40 percent in the real

currencies indexes over the past quarter-century was also a feature of the alternative indexes, an indication that the lack of drift is not an artifact of chained weights.

20. The failure of the real OITP index to exhibit noticeable longterm downward drift over the past two decades is somewhat puzzling because the currencies of emerging-market economies may be expected to experience secular real appreciation against the dollar and other major currencies. Balassa (1964) and Samuelson (1964) argued that because technological progress tends to be concentrated in the production of internationally tradable goods, economies that experience sustained rapid technological progress, such as many emergingmarket economies, should exhibit a long-term rising real exchange rate in terms of price indexes, such as consumer price indexes, that include nontradables. See Bela Balassa (1964), "The PurchasingPower Parity Doctrine: A Reappraisal," Journal of Political Economy, vol. 72 (December), pp. 584-96; and Paul A. Samuelson (1964),

"Theoretical Notes on Trade Problems," Review of Economics and Statistics, vol. 46 (May), pp. 145-54.
4. Nominal major currencies and G-10 indexes of the foreign exchange value of the U.S. dollar, 1980-2004

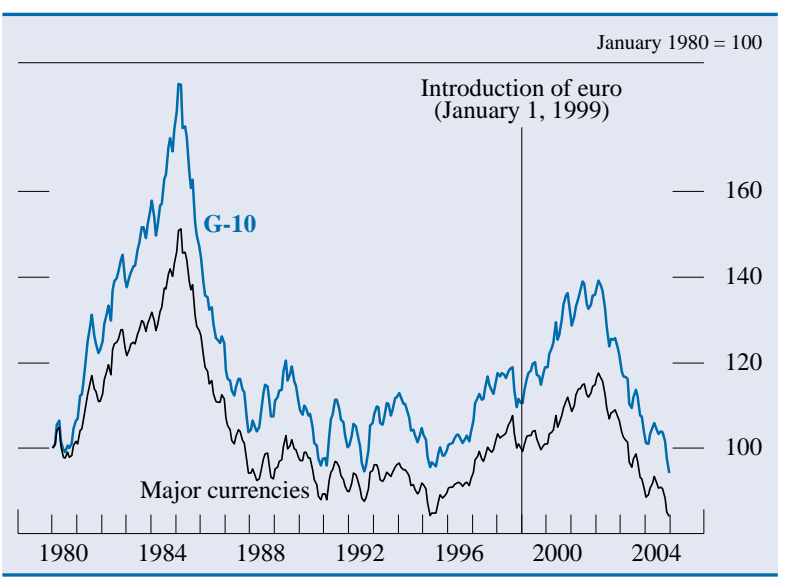

NOTE. Data are monthly averages of daily values.

OITP index that was noted earlier. This difference illustrates dramatically that nominal exchange rate indexes are poor measures of trade competitiveness when inflation rates abroad differ widely from those in the United States.

Two dollar indexes, the major currencies index and its precursor, the G-10 index, cover currencies of economies that experienced inflation rates roughly similar to those in the United States during the past three decades. Thus, even without adjustments for prices, the evolution of these indexes can be informative regarding long-term trends in the competitiveness of U.S. goods relative to those of other industrial economies (figure 4). ${ }^{21}$ The G-10 dollar index, created in the late 1970s, was based on ten major currencies, including five European currencies that later merged into the euro. With the adoption of the euro by Germany, France, Italy, the Netherlands, Belgium, and Luxembourg at the beginning of 1999, this index effectively became a six-currency index. The major currencies index includes the same six currencies as the G-10 index - the euro, Canadian dollar, Japanese yen, British pound, Swiss franc, and Swedish krona - and also the Australian dollar. The main difference between the two indexes is that the major currencies index gives considerably less weight to the euro and more weight to the Canadian dollar than does the G-10 index. ${ }^{22}$ A second important difference is in the updating of the currency weights: The major currencies index uses weights that vary by year,

21. Although no longer maintained by the Board's staff, the G-10 index is still followed in the financial community, in part because it forms the basis of certain exchange-traded futures contracts.

22. The currency weights in the G-10 index are multilateral weights, which are defined as the share of total trade (exports plus 
whereas the currency weights of the G-10 index are fixed.

Even though these two nominal indexes have evolved roughly similarly on balance over the past twenty-five years, the G-10 index has witnessed fluctuations of a greater amplitude during certain subperiods, especially from 1980 to 1988 and again from 1999 to the present. These two subperiods were characterized by greater volatility of the dollar against the European currencies than against several other currencies, especially the Canadian dollar. The large weight of the euro (and of its precursor currencies) in the G-10 index, together with the fact that the swings in the dollar's exchange value against the euro were large over the two subperiods, explains most of the higher amplitude of the swings in the G-10 index. The staff views the major currencies index as a better indicator of the evolution of the competitiveness of U.S. products against those made in the other majorcurrency economies, especially over the period since the euro was introduced as a traded currency.

\section{REVISION OF CURRENCY WEIGHTS AND IMPLEMENTATION OF METHODOLOGICAL CHANGES}

Because the currency weights of the staff's dollar indexes are based on annual data on international trade, these weights will change as new trade data are received. For example, during most of 2003, index calculations for days or months in 2003 were based on annual trade data for 2001, the latest year for which such data were then available. In late 2003, after annual trade data for 2002 were published, the currency weights for 2003 were updated, and that revision led to an update of the indexes as well. After 2003 trade data became available late in 2004, the indexes for dates in 2003 were updated yet again. In addition, past international trade data are occasionally re-benchmarked and revised to incorporate new information on trade flows and to correct previous errors and omissions. Such changes may lead to further revisions of the trade-based currency weights. ${ }^{23}$

\footnotetext{
imports) of the foreign economies in the index. Largely because the trade figures underlying these multilateral trade weights included trade among the six countries that eventually became part of the euro area, the weight of the euro in the G-10 index (obtained by summing the individual currency weights for Germany, France, Italy, the Netherlands, and Belgium/Luxembourg) is larger than its weight in the major currencies index.

23. Such revisions are usually minor for years that precede the immediately previous year.
}

Another source of occasional revisions stems from methodological changes. Three such changes have been implemented since the current set of dollar indexes was introduced in late 1998. First, after Greece adopted the euro in January 2001, trade data for Greece were included to compute the euro's weights in the dollar indexes. ${ }^{24}$ Because Greece is a relatively small economy and much of its international trade occurs with other euro-area countries, its inclusion in the euro-area aggregate raised the euro's combined weight in the broad dollar index less than 0.1 percentage point. Second, starting with the annual revision published in January 2002, agricultural exports are no longer subtracted from U.S. exports in the computations of the weights, either for the current period or for past periods. This change was motivated, in part, by the increasing level of processing incorporated in U.S. agricultural exports, which makes them less like pure commodities and more like differentiated products. This modification simplified the calculation of the bilateral export weights without changing them significantly.

Prompted in part by Sweden's referendum in September 2003, in which voters decided not to adopt the euro as their national currency, the staff made a third methodological change. It revised its practice regarding the treatment of intra-EU trade in the calculation of the third-market competitiveness weights. Although trade among euro-area countries continues to be excluded from these calculations, starting with the annual revision of weights published in December 2003, trade between the euro-area countries and both Sweden and the United Kingdom, as well as trade between Sweden and the United Kingdom, is now included for the current year and for past years. Because these three economies have important trade ties with each other and because they are also important trading partners of the United States, this methodological change resulted in some fairly substantial increases in the third-market competitiveness weights and hence also in the combined weights of the euro, the British pound, and the Swedish krona for the entire sample period.

These methodological changes were announced on the Board's website when they were introduced. The staff will continue to announce these and other revisions, including changes in index weights caused by shifting patterns of international trade and changes in component currencies, as they are implemented.

24. Because the drachma was not in the broad dollar index before 2001 , the total number of currencies in that index remained unchanged at twenty-six. 